\title{
Risk of water pollution due to ash-sludge mixtures: column trials
}

\author{
Y. Pousada-Ferradás $\cdot$ S. Seoane-Labandeira $\cdot$ \\ A. Mora-Gutierrez $\cdot$ A. Núñez-Delgado
}

Received: 8 April 2011/Revised: 5 July 2011/Accepted: 10 September 2011/Published online: 24 November 2011

(c) CEERS, IAU 2011

\begin{abstract}
The purpose of this work was to study the risks of water pollution due to the use of mixtures containing wood ash and sewage sludge. Mixtures including sludge and ash may be recycled as fertilizers, and they are economical as they do not integrate commercial limes, but Escherichia coli counts may keep significantly high in such mixtures, because their $\mathrm{pH}$ is not alkaline enough. In view of that, it seems interesting to study the E. coli survival in lixiviate from ash-sludge mixtures including limes rather than from ash-sludge mixtures alone. Two kinds of experiments were performed using laboratory column trials under saturated flow conditions. The first experiment investigated the chemical leaching behaviour of a mixture of $70 \%$ timber-industry wood ashes and $30 \%$ urban sewage sludge (\% dry weight) at doses equivalent to 10 and $30 \mathrm{Mg} / \mathrm{ha}$. The second experiment studied the survival of $E$. coli in lixiviates generated from $30 \mathrm{Mg} / \mathrm{ha}$ of a mixture consisting in $75 \%$ wood ash, $20 \%$ sewage sludge and $5 \%$ quicklime ( $\%$ dry weight). In the first experiment, admixture of the ash and sludge achieved a stabilization of elements such as aluminium, iron, magnesium, nickle, carbon monoxide, cadmium, chromium and molybdenum that reduced their solubility compared with that in the ash or sludge alone. Significant
\end{abstract}

Y. Pousada-Ferradás · S. Seoane-Labandeira ·

A. Núñez-Delgado $(\square)$

Dept. Edafología y Química Agrícola (Soil Sci. and Agric.

Chem.), Univ. Santiago de Compostela, Escuela Politécnica

Superior, Campus Univ. s/n, 27002 Lugo, Spain

e-mail: avelino.nunez@usc.es

\section{A. Mora-Gutierrez}

Laboratorio de Referencia de E. coli, Dept. Microbiología y Parasitología, Univ. Santiago de Compostela. Fac. Veterinaria, Campus Univ. s/n, 27002 Lugo, Spain solubilisation of heavy metals was not observed, with overall minor risk of chemical water pollution. In the second experiment, although including quicklime $E$. coli counts were still detected in the lixiviate, indicating risk of water contamination.

Keywords Escherichia coli counts · Lixiviate · Sewage sludge $\cdot$ Wood ash

\section{Introduction}

Linked to minimizing the risks of water pollution, the management of organic waste products is a key element of any regional environmental policy. Increasingly, decision makers aim to use these products in some way, rather than by simply dumping, storing or incinerating them (Sumner 2000). A common option is to use organic wastes as fertilizer and/or soil conditioner, thus making productive use of their nutrient content, and taking advantage of the soil's ability to neutralize and/or to slow the passage of contaminants into water bodies.

In the timber industry, many factories use non-timber waste biomass as a combustion fuel for energy production. This gives rise to a wood ash with characteristics dependent on the raw material and on the combustion process (Demeyer et al. 2001; Pitman 2006). Although particle size shows correlations with certain physicochemical properties, in general the main components of these ashes are calcium, potassium and magnesium. Sulphur, phosphorus and manganese are present at concentrations of about $1 \%$, while iron, aluminium, copper, zinc, sodium, silicon and boron are present at lower concentrations. Nitrogen is present in very small quantities, since it is volatilized during combustion as $\mathrm{NH}_{3}, \mathrm{NO}_{x}$ or $\mathrm{N}_{2}$. Neutralizing 
capacity is about $25-50 \% \mathrm{w} / \mathrm{w}$ of that of calcium carbonate (Sumner 2000). Wood ashes with similar characteristics are used for liming and fertilizing acid soils. However, Lundström et al. (2003a) found that treatment of certain types of soil with ashes may lead to important changes in the soil's water quality, notably in inorganic aluminium content, organic carbon content, sulphate content and nitrate content (Lundström et al. 2003b), as well as low-molecular-weight compounds (Holmström et al. 2003).

Sludge from urban Wastewater treatment plants (WTTPs) are likewise produced in very large amounts. The composition of the sludge depends on the characteristics of the waste entering the WTTP, and on the treatment procedures applied to the wastes and the resulting sludge. In general, this sludge is rich in organic matter, and contains variable amounts of nitrogen, phosphorus and potassium and in some cases significant amounts of heavy metals, notably zinc, chromium, copper and lead (Canet et al. 1998). The use of WTTP sludge as organic soil conditioners and fertilizers has increased. For example, data for the year 2005 from the Spanish Ministry of the Environment indicate that $65 \%$ of WTTP sludge produced in Spain was applied to agricultural land. Despite their widespread agricultural use, WTTP sludge may indicate significant handling problems for farmers. Some studies have detected apparent contamination of water bodies, mainly by nitrates and phosphates, in areas in which WTTP sludge are applied to agricultural land (Shepherd and Withers 2001; Cravotta 1998). It is thus important to pay special attention to these ions, in view of their repercussions for drinking water quality or algae proliferation. It is also important to consider the levels of microbial pathogens and indicators of faecal contamination (Wéry et al. 2008), which may be drastically reduced by appropriate chemical treatments.

Various authors have studied mixtures of coal ash and diverse biosolids (Jackson et al. 1999; Schumann and Sumner 2000; Abbott et al. 2001), and have identified several mixtures with apparently useful properties. Kuba et al. (2008) have also studied admixture of wood ash to organic wastes in order to improve compost.

In the present study, it is used a mixture of a timberindustry wood ash (70\% dry weight) and a WTTP sludge (30\% dry weight) with high bioavailable levels of calcium, potassium and magnesium, and acceptably low bioavailable levels of heavy metals (Pousada et al. 2003). A priori, however, it cannot be ruled out the possibility that leaching by rainfall and surface runoff may lead to the formation of more soluble forms of these components which are initially less mobile but may eventually give rise to contamination of water bodies (Gitari et al. 2010). With the challenge of assessing this risk of water pollution, there were performed laboratory column trials, as per Núñez et al. (1997), aimed at characterizing nutrient and contaminant transport from ash-sludge mixtures. Column trials and leaching tests have been used in related studies (Chirenje et al. 2002; Dalgren et al. 2011; Pettersson et al. 2008a, b; Stiernström et al. 2011; Yeheyis et al. 2009), even as a tool for characterizing nutrient and contaminant release from wood ash or ashes from co-combustion of sewage sludge to the soil and groundwater, but not from wood ash/sewage sludge mixtures in this way. Column trials were also performed with the aim of studying the $E$. coli survival in lixiviate from ash-sludge mixtures including limes rather than from ashsludge mixtures alone, which, as long as it is known, was not previously done. The research was carried out in 2006, at the Department of Soil Science and Agricultural Chemistry and at the Reference Laboratory on E. coli, both in the city of Lugo, Univ. Santiago de Compostela (Spain).

\section{Materials and methods}

Two kinds of experiments were carried out in order to determine, in first place, the chemical leaching behaviour of a sewage sludge and wood ash mixture and in second place the survival of $E$. coli in lixiviates generated from a mixture of sewage sludge, wood ash and quicklime. Then, two types of mixtures were prepared for the experiments due to various considerations that connect it. On the one hand, mixtures including only sludge and ash may be recycled as fertilizers, and they are more economical as they do not integrate commercial limes. On the other hand, our previous studies on storage experiments have shown that E. coli counts keep significantly high in mixtures including only sludge and ash, because their $\mathrm{pH}$ is not alkaline enough. Samaras et al. (2008) also reported pH levels below 10 in mixtures 1:1, 1:2 and 2:1 (dry weight basis, w/w) of fly ash-sewage sludge. In view of that, it seems interesting to study the $E$. coli survival in lixiviate from ash-sludge mixtures including limes rather than from ash-sludge mixtures alone.

Chemical analysis of lixiviates from the ash-sludge mixture

With regard to the first experiment, the ash-sludge mixture (70:30\% by dry weight) was prepared as described by Pousada et al. (2003). The ashes were bottom ashes from the furnace of a timber-processing factory run by Tablicia S.A. (Nadela, Lugo, Spain); the sludge was from the WTTP of the city of Lugo. The mixture was stored for 60 days after preparation, to ensure physical and chemical stabilization. Column trials were performed with four polyethylene columns $(15 \mathrm{~cm}$ high, $5.5 \mathrm{~cm}$ internal diameter at top, $4.7 \mathrm{~cm}$ internal diameter at bottom). Columns were not packed with soil or any other matrix. To prevent 
losses of solid material, the bottom of the column was covered with a layer of cotton cloth and a 1-mm-mesh nylon gauze. The columns were loaded with 1.73 or $5.20 \mathrm{~g}$ of ash-sludge mixture (equivalent to 10 or $30 \mathrm{Mg} / \mathrm{ha}$ ) (i.e. $n=2$ columns per treatment), then fed with distilled water from a main tank via an intermediate tank fitted with a float control valve, with the aim of maintaining a constant level and thus saturation flow in the columns. The bottom exit of each column fed to $250-\mathrm{cm}^{3}$ bottles. During the experiment, $\mathrm{N}_{2}$ gas was circulated through the tubing when liquids were not being passed, to ensure reducing conditions at all times (as per Núñez et al. 1997). Lixiviates were collected in a total of 12 bottles per column, the first 7 containing $120 \mathrm{~cm}^{3}$ of percolate, the remaining 5 containing $240 \mathrm{~cm}^{3}$ of percolate, giving a total 2.04 litres per column. The total time of the experiment was 10 and onehalf hours. The amount of water is equivalent to $1,176 \mathrm{~mm}$ of rain (i.e. 1 year of precipitation in Lugo, Spain). In all lixiviates $\mathrm{pH}$ and electrical conductivity (EC) were determined by electrometric methods immediately after collection. Chemical oxygen demand (COD) was determined on the basis of oxidation of dichromate in acid medium (APHA 1998). Ammonium and nitrates, as well as soluble phosphorus, were determined as per APHA (1998). In addition, $\mathrm{Ca}, \mathrm{Mg}, \mathrm{Na}, \mathrm{K}, \mathrm{Fe}, \mathrm{Al}, \mathrm{Mn}, \mathrm{Zn}, \mathrm{Ni}, \mathrm{Cu}, \mathrm{Co}, \mathrm{Cd}$, $\mathrm{Cr}, \mathrm{Pb}, \mathrm{B}, \mathrm{As}, \mathrm{Mo}$, and $\mathrm{S}$ were determined by inductively coupled plasma optical emission spectroscopy (ICP-OES).

Microbiological analysis of lixiviates from the ashsludge-quicklime mixture

Only one column was used for this experiment, and all its components were sterilized. The glass column of a 33.2$\mathrm{cm}^{2}$ transversal section had an adapted layer of two meshes with a cotton cloth between them. In order to work aseptically, the system was cleaned with ethanol before performing the experiment. The mixture used consisted of $75 \%$ wood ash, 20\% sewage sludge, and 5\% quicklime from CEDIE S.A. (Barco de Valdeorras, Ourense, Spain) (\% dry weight). The mixture was stored for 7 days to ensure physical and chemical stabilization before being introduced into the column. This column received $829 \mathrm{~mm}$ of distilled water corresponding to $70 \%$ of the rainfalls in Lugo during a 1-year period. A total of eight samples were regularly collected in sterilized PET bottles of $100 \mathrm{~mL}$. The total volume of circulating water was $2.7 \mathrm{~L}$ (according to the rain falling simulated and the column surface) with a leaching time of $7 \mathrm{~h}$.

The Escherichia coli most probable number (E. coliMPN) was determined using batches with nine tubes of Mac Conkey broth per sample. Three of the tubes (10 mL double concentration of Mac Conkey medium), were inoculated with $10 \mathrm{~mL}$ of sample; three tubes
(5 mL simple concentration) were inoculated with $1 \mathrm{~mL}$; and the other three (5 mL simple concentration) with $0.1 \mathrm{~mL}$. The inoculated tubes were incubated $24-48 \mathrm{~h}$ at $37^{\circ} \mathrm{C}$. Those tubes which showed colour change due to the acidity, turbidity and gas production were considered positive for total coliforms. To confirm the $E$. coli presence, new tubes were inoculated with those positive and incubated $48 \mathrm{~h}$ at $44^{\circ} \mathrm{C}$. The E. coli-MPN is calculated through a table according to the number of positive tubes at $44^{\circ} \mathrm{C}$.

The experiments above described were independent and adjusted to their different purposes.

\section{Results and discussion}

Chemical analysis

The leaching time-courses from the first experiment are summarized in Fig. 1 for pH, Fig. 2 for EC, and Figs. 3, 4, 5, 6, 7, 8, 9 for different components.

The $\mathrm{pH}$ profiles (Fig. 1) were very similar in the four columns, remaining between 6 and 7.5 throughout the trials, although values were slightly higher in columns containing the ash-sludge mixture at a dose equivalent to $30 \mathrm{Mg} / \mathrm{ha}$. The frequent short-term increases in $\mathrm{pH}$ seem to indicate loss of basic cations to the aqueous medium at different stages in the trials, possibly due to the presence in the mixture of substances with different weathering, so that in the end $\mathrm{pH}$ remains relatively stable despite the leaching. This explanation is plausible given that bottom ashes typically contain components that have been subject to varying degrees of combustion, and as a result both oxides and carbonates of calcium, magnesium and potassium may be present; these compounds clearly have different solubility in water, and thus their passage to the soluble form at different times favours maintenance of near-neutral $\mathrm{pH}$.

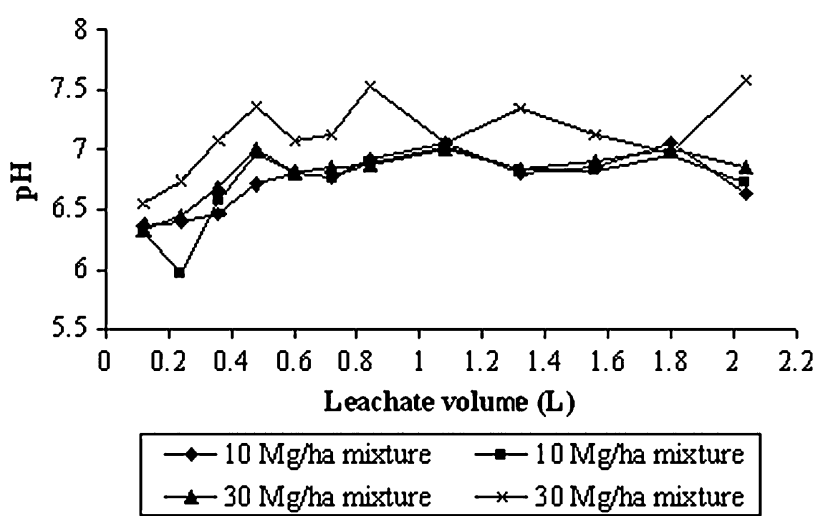

Fig. 1 Time-courses of $\mathrm{pH}$ in the column leachates 


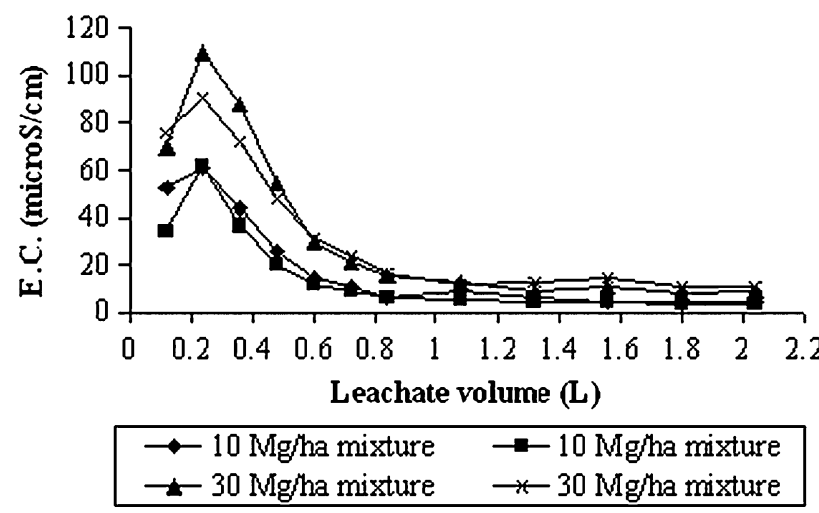

Fig. 2 Time-courses of electrical conductivity (EC) in the column leachates

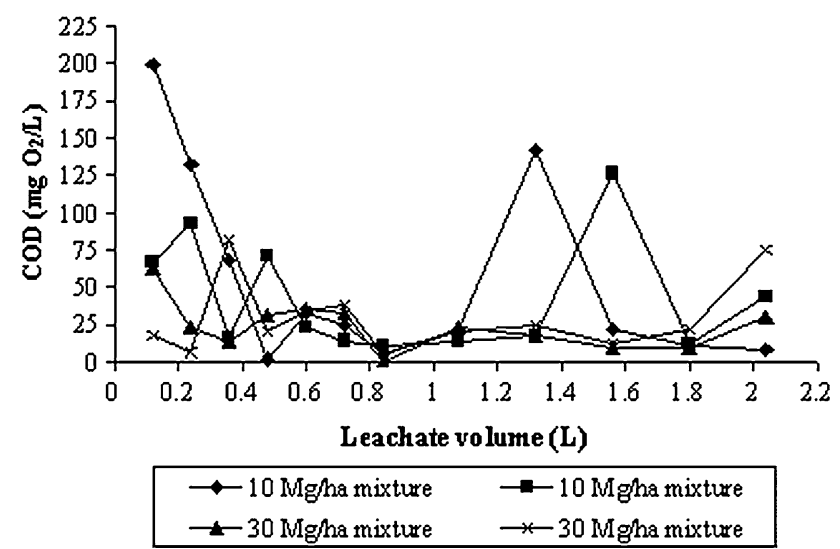

Fig. 3 Time-courses of COD in the column leachates

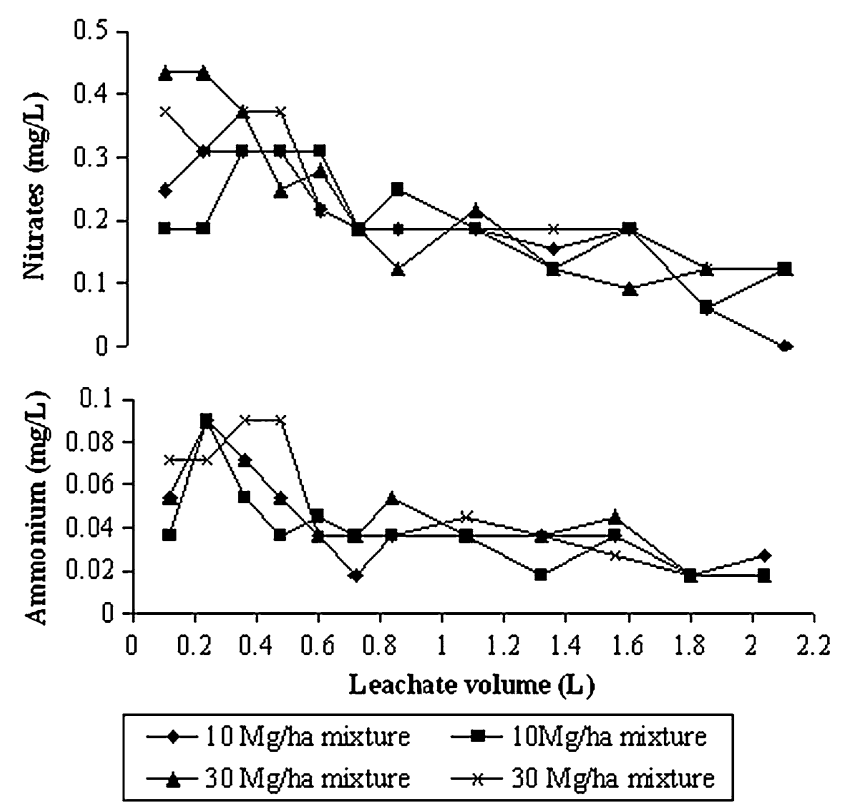

Fig. 4 Time-courses of ammonium and nitrate concentrations in the column leachates
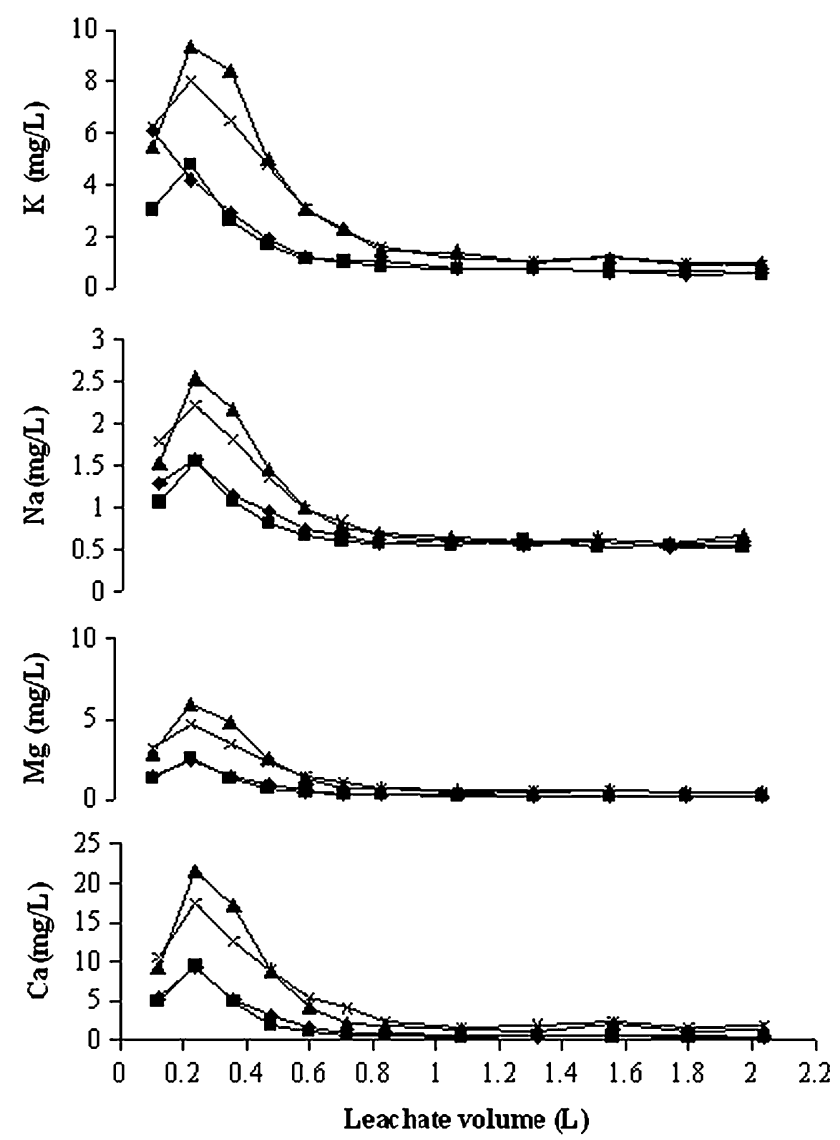

$\begin{array}{ll}\rightarrow-10 \mathrm{Mgha} \text { mixture } & \rightarrow-10 \mathrm{Mg} \text { ha mixture } \\ \rightarrow-30 \mathrm{Mgha} \text { mixture } & \rightarrow-6 \mathrm{Mg} \text { /ha mixture }\end{array}$

Fig. 5 Time-courses of $\mathrm{Ca}, \mathrm{Mg}, \mathrm{Na}$ and $\mathrm{K}$ concentrations in the column leachates

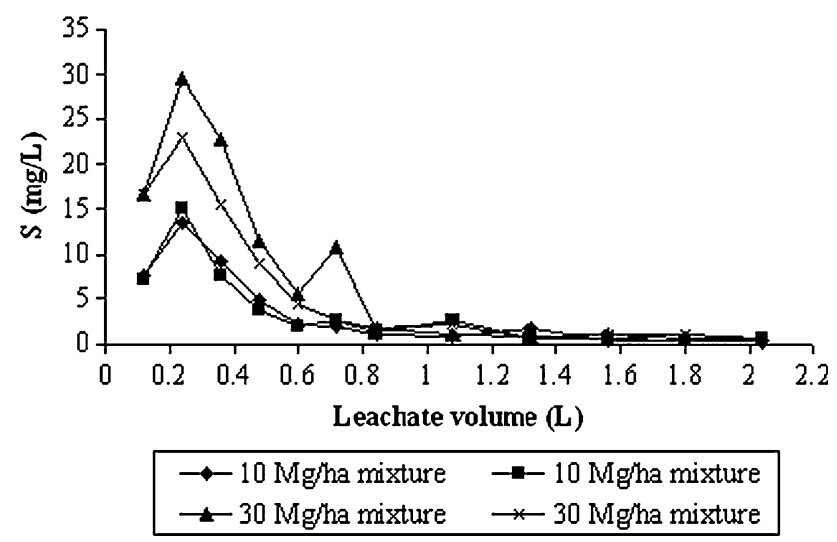

Fig. 6 Time-courses of S concentration in the column leachates

Electrical conductivity (Fig. 2) likewise showed similar behaviour in all four columns, although values were the highest in the columns containing the higher ash-sludge dose. EC increased rapidly in the first few samples, then gradually declined, reaching a plateau after about the first 

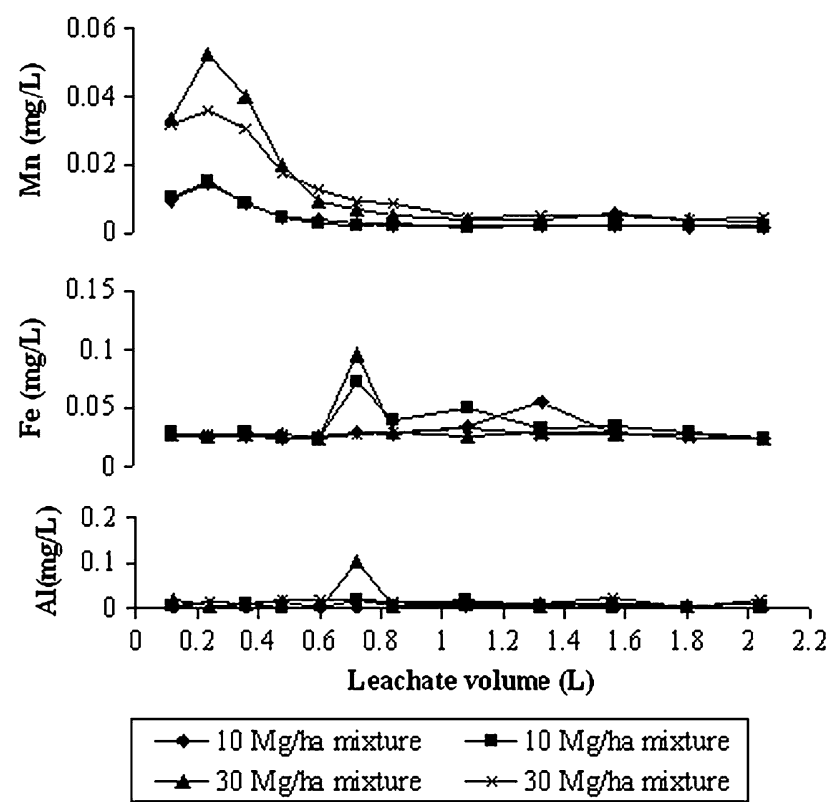

Fig. 7 Time-courses of $\mathrm{Al}, \mathrm{Fe}$ and $\mathrm{Mn}$ concentrations in the column leachates
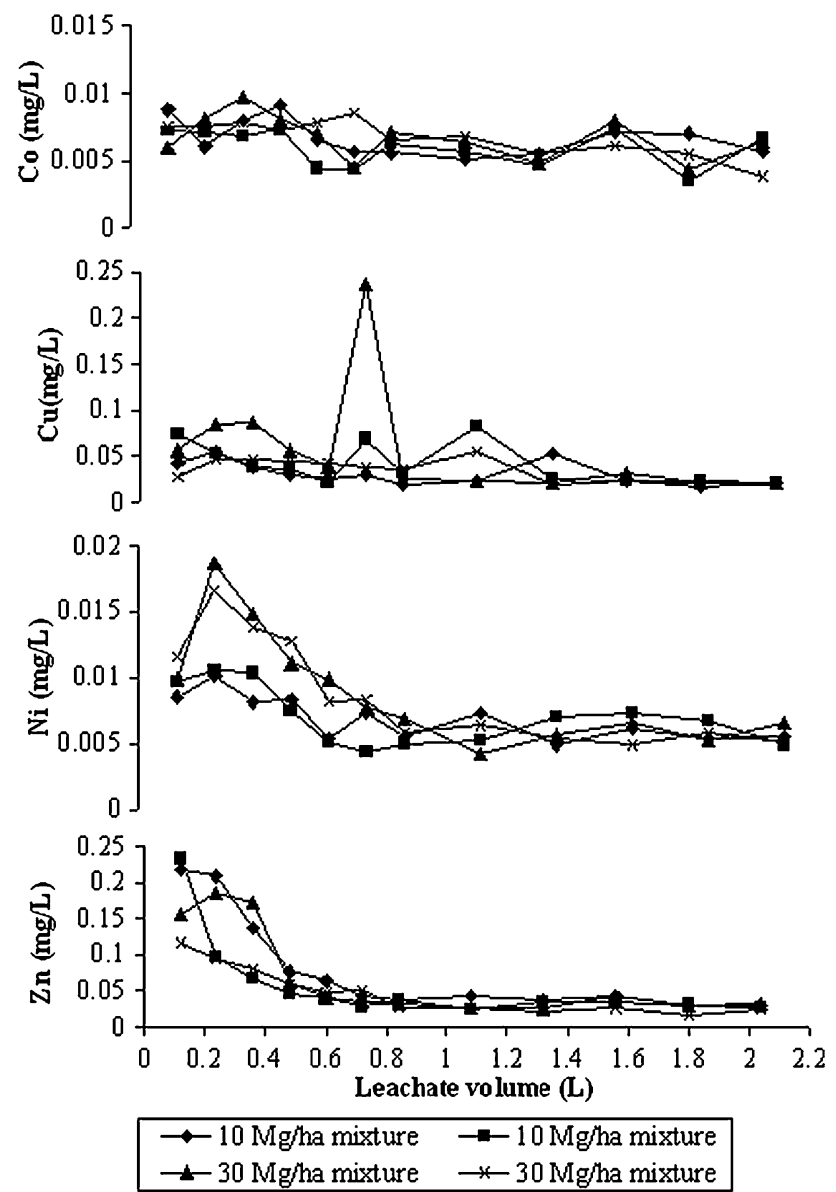

Fig. 8 Time-courses of $\mathrm{Zn}, \mathrm{Ni}, \mathrm{Cu}$ and $\mathrm{Co}$ concentrations in the column leachates
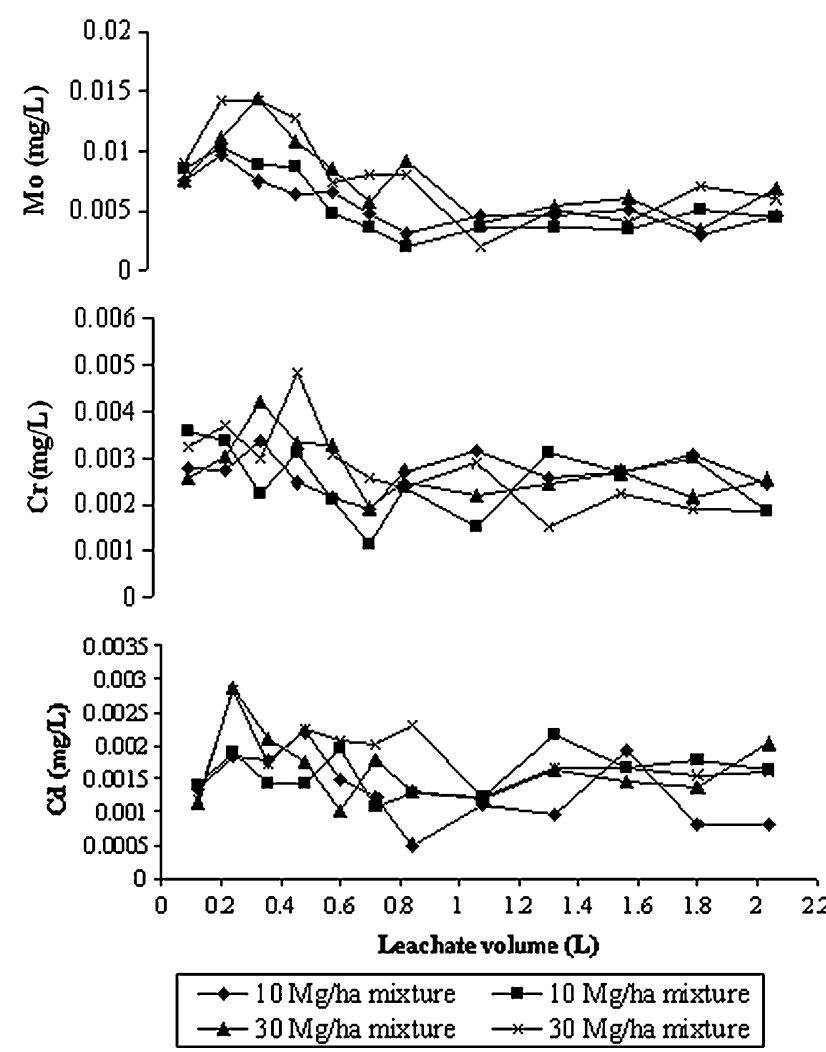

Fig. 9 Time-courses of $\mathrm{Cd}, \mathrm{Cr}$ and Mo concentrations in the column leachates

litre of lixiviate, which is characteristic in experiments of this type. In other words, the weathering of the most labile components produced considerable ionic load at the outset; once these ions had been leached, ionic load in the lixiviates remained almost constant, but much lower, reflecting weathering of less labile components with slower reaction rates; this effect was sufficient to maintain $\mathrm{pH}$ at a more or less constant level until the end of the experiment (total lixiviate volume $2.04 \mathrm{~L}$ ) (Figs. 1, 2).

Chemical oxygen demand in lixiviates showed frequent oscillations throughout the study period (Fig. 3), reflecting the solubilisation of different oxidizable substances at different times in the experiment. It seems likely that the unequal degree of combustion of the ash components leads to the presence of substances with differing degrees of oxidation, and thus differing degrees of reactivity with dichromate. Overall, the highest levels of COD were reached in the columns containing the ash-sludge mixture at the lowest dose $(10 \mathrm{Mg} / \mathrm{ha})$, indicating that the higher ratio of leaching water to ash-sludge mixture in these columns facilitated the leaching of oxidizable substances.

Ammonium and nitrates were present in the lixiviates at low concentrations throughout the experiment (Fig. 4). Ammonium content was rather higher until $0.6 \mathrm{~mL}$ of percolate (about $0.1 \mathrm{mg} / \mathrm{L}$ ), but from this point values were 
lower than $0.05 \mathrm{mg} / \mathrm{L}$. Nitrate content at all times remained below $0.05 \mathrm{mg} / \mathrm{L}$, though with rather higher levels at the beginning of the experiment and in columns with a higher dose of ash-sludge mixture. Total nitrate loss was also higher from these columns. Nitrogen lost as ammonium accounted for only $1.27 \%$ (columns with the dose of $10 \mathrm{Mg} / \mathrm{ha}$ ) or $0.43 \%$ (columns with $30 \mathrm{Mg} / \mathrm{ha}$ ) of the total amount of nitrogen present in the mixture. Nitrogen lost as nitrate accounted for $9.71 \%$ (columns with $10 \mathrm{Mg} / \mathrm{ha}$ ) or $3.78 \%$ (columns with $30 \mathrm{Mg} / \mathrm{ha}$ ) of the total amount of nitrogen present in the mixture. In both cases, then, the total loss was small, and concentrations in the lixiviate were consistently low. Due to the reducing conditions prevailing in the columns (i.e. saturation water content), it seems unlikely that oxidation of ammonium or nitrates could have occurred, so that the measured levels of both ions should be directly related to starting contents in the mixture.

Phosphorus content in lixiviates was at all times very low (data not shown), which was expected since this element is present only at low concentrations in both ashes and sludge. Phosphorus contents were somewhat higher in the columns containing the highest dose of ash-sludge mixture.

Calcium, magnesium, sodium and potassium (Fig. 5) showed very similar behaviour, with concentration increasing very rapidly at the beginning of the experiment, peaking at $0.24 \mathrm{~L}$, and subsequently declining to a plateau from about $0.80 \mathrm{~L}$ onwards. Electrical conductivity showed a very similar time-course. The cations present at the highest concentration were calcium and potassium, which reached peak concentrations of 21.62 and $9.34 \mathrm{mg} / \mathrm{L}$, respectively. In all cases, concentrations were higher in lixiviates from columns containing the highest dose of ashsludge mixture $\left(30 \mathrm{Mg} \mathrm{ha}^{-1}\right)$. When concentrations are expressed in terms of $\mathrm{mg}$ per $\mathrm{kg}$ of ash-sludge mixture, the total values obtained at the end of the experience (for 10 and $30 \mathrm{Mg} / \mathrm{ha}$ doses, respectively) were 2,058.55 and $1,848.04 \mathrm{mg} / \mathrm{kg}$ for $\mathrm{Ca}, 1,613.49$ and $1,023.02 \mathrm{mg} / \mathrm{kg}$ for $\mathrm{K}, 658.93$ and $528.77 \mathrm{mg} \mathrm{kg} /$ for $\mathrm{Mg}$, and 847.02 and $369.30 \mathrm{mg} / \mathrm{kg}$ for $\mathrm{Na}$. The highest $\mathrm{mg} / \mathrm{kg}$ concentrations in columns containing the lowest doses are attributable to the fact that both types of column received the same amount of water, leading to greater solubilisation from the lower dose columns due to greater contact between the leaching water and the mixture. Solubilised $\mathrm{Ca}$ accounted for 23.1 and $20.7 \%$ of the total potentially available amounts at 10 and $30 \mathrm{Mg} / \mathrm{ha}$, respectively, which indicates there is slow release of Ca during percolation. Solubilised $\mathrm{Mg}$ accounted for 60.6 and $46.7 \%$ of the total potentially available amounts at 10 and $30 \mathrm{Mg} / \mathrm{ha}$, respectively, meaning that release was higher from columns with the lowest dose; though about $40 \%$ of potentially available $\mathrm{Mg}$ still remained. Solubilised K was 134.8 and $85.4 \%$ of the total potentially available amounts at 10 and $30 \mathrm{Mg} / \mathrm{ha}$, respectively; in other words, $\mathrm{K}$ release affected not only potentially available $\mathrm{K}$, but also less bioavailable forms. Obviously, these values would be different if the soil was present in the columns, but nevertheless suggest that basic cations-notably $\mathrm{Ca}$ and $\mathrm{Mg}$ - will be released gradually from ash-sludge mixtures of this type, indicating that they may be of value for the liming of acid soils.

Sulphur (Fig. 6) showed similar behaviour to that of the basic cations, with a peak at $0.2 \mathrm{~L}$ and subsequent plateauing out. Concentrations in lixiviate $(\mathrm{mg} / \mathrm{L})$ were higher for columns with the highest dose of the ash-sludge mixture.

Aluminium, iron and manganese were present, as expected, at very low concentrations in lixiviates (Fig. 7), given the near-neutral $\mathrm{pH}$ of the columns.

The remaining elements $(\mathrm{Zn}, \mathrm{Ni}, \mathrm{Cu}, \mathrm{Co}, \mathrm{Cd}, \mathrm{Cr}$ and Mo) were all present at very low concentrations in lixiviates (Figs. 8, 9), with no differences between the two doses of the ash-sludge mixture. Except for zinc, all these elements showed closely similar behaviour. The highest zinc concentrations were observed in the earliest lixiviates, and from $0.8 \mathrm{~L}$ onwards zinc concentration plateaued out to very low levels. This was an expected result given that zinc was present in the mixture at higher quantities than the rest of these elements. The small quantities of these elements (Al, Fe, Mn, Ni, Co, Cd, $\mathrm{Cr}$ and $\mathrm{Mo}$ ) released in lixiviates indicate that admixture of the ash and sludge achieved a stabilization that reduced their solubility if compared with that in the ash or sludge alone. This view is supported by the fact that the content of these elements in lixiviates were similar regardless of ash-sludge mixture dose. This behaviour has been observed in prolonged leaching cycles, even when using much greater quantities of material and with metal loads much higher than these used in the present study (Abbott et al. 2001).

In general, except in the first part of the experience, the values found in the lixiviates for the different ions and different conditions are similar to those reported by other authors in experiences with lysimeters (Kahl et al. 1996), or to those measured in brooks flowing in Finland before and after ash treatment (Tulonen et al. 2002).

The results obtained in the present study indicate that admixture of ash and sludge constrains the release of potentially harmful ions in lixiviates. Of the constraining factors, the most important appeared to be those related to the evolution of organic matter, and to the dissolution of oxides and carbonates present in the mixture. As a result, the mixture maintained near-neutral $\mathrm{pH}$, despite the large volume of water percolated through the column, and gradually released a considerable amount of calcium and magnesium. 
Although during the experiments some organic carbon was leached from the columns, apparently, this had no effect on the mobilization of heavy metals. In fact, the neutral $\mathrm{pH}$ generally prevailing in the columns prevented solubilisation of most metals. This behaviour may be different when the ash-sludge mixture is incorporated into the soil, since the interactions with the soil medium may modify the release of some of these elements, as found by Al-Wabel et al. (2002) and McLaren et al. (2003).

\section{Microbiological analysis}

With regard to the second experiment on E. coli survival, a parallel test of storage of solid mixtures in laboratory conditions was performed with an identical mixture to that used in the second type of column. In this parallel test, the E. coli counts were quite high only the first day (MPN $=100-999 / \mathrm{g}$ ), and they decreased from this point to $<10$ at day 10 , maintaining this value until the last determination at day 29. The $\mathrm{pH}$ of the solid mixture was progressively decreasing from the beginning of the storage (pH 12.46) to day 10 (pH 12.26), with a final value of 8.92 at day 29. These data mean that during the 10 first days of incubation (time superior to the 7 days of storage previous to the introduction of the mixture into the column), the $\mathrm{pH}$ of that solid mixture kept above 12. In a previous study with different mixtures of sludge and commercial limes, it was reported the necessity of a minimum $30 \%$ content of lime to maintain a pH $>12$ (Quiroga et al. 2005). Samaras et al. (2008) studying different mixtures of fly ash-sewage sludge, a 1:1 lime-sludge mixture, and a 0.5:0.5:2 fly ashlime-sludge mixture, verified that only the lime-sludge mixture maintained a $\mathrm{pH}>12$ during the 35 days of experiment, while the other mixtures showed a $\mathrm{pH}$ ranging from 7.5 to 10 .

In the percolates generated in the experiment with the second type of column, the highest level was detected in

Table 1 Cumulated volumes, $\mathrm{pH}$ and $E$. coli counts in the lixiviates corresponding to the experiment with the second mixture and the second type of column

\begin{tabular}{lllc}
\hline $\begin{array}{l}\text { Sample } \\
\text { number }\end{array}$ & $\begin{array}{l}\text { Cumulated } \\
\text { sample } \\
\text { volume (L) }\end{array}$ & $\mathrm{pH}$ & $\begin{array}{l}\text { E. coli } \\
(\mathrm{MPN} / 100 \mathrm{~mL})\end{array}$ \\
\hline 1 & 0.30 & 6.31 & 23 \\
2 & 0.65 & 6.64 & 4 \\
3 & 1.00 & 6.98 & 15 \\
4 & 1.35 & 6.94 & 4 \\
5 & 1.70 & 6.85 & 7 \\
6 & 2.05 & 6.93 & 4 \\
7 & 2.40 & 7.06 & 9 \\
8 & 2.75 & 7.01 & 4 \\
\hline
\end{tabular}

the first sample (MPN 23/100 mL; Table 1). The following samples showed oscillating values but lower than the first one. Due to the aseptic conditions used before the components of the mixture were introduced in the column, the E. coli detected in lixiviates must have initially transferred from the solid mixture to the aqueous medium. Therefore, it seems that there was no total inactivation of $E$. coli at the time of introducing the mixture in the column. It seems also reasonable to think that improved conditions of high humidity, nutrients, and a more moderate $\mathrm{pH}$ provided by the mixture once received the distilled water (lixiviates with $\mathrm{pH}$ values between 6.31 and 7.06; Table 1) enabled a certain microbial proliferation; specially if compared with a more alkaline and less humid condition of the dried-solid mixture. It is supposed that from the beginning of the flow and at least during a time, the mixture continues supplying bacteria to the liquid medium where the microorganisms may proliferate. It must be also considered that flowing water can remove part of the bacteria out in lixiviates. It must be borne in mind that the $\mathrm{pH}$ of the solid mixture placed in the column will not maintain the same high value (>12) when washing with distilled water (initial $\mathrm{pH}$ of 5.6), suffering progressive dissolution of chemical components. Determination of $\mathrm{pH}$ in lixiviates showed values below 7.1 (Table 1); in fact, the $\mathrm{pH}$ was increasing from 6.31 in the first sample of percolate to 6.98 in the third, decreasing to 6.85 in the fifth and, finally, slightly increasing again above 7 in samples seventh and eighth. Thus, this study shows that even though quicklime was included in the second mixture, E. coli was able to proliferate, in certain grade, in it and its lixiviate. In view of the results, if the objective is performing a mixture of sludge-ash-limes and/or other components with reduced counts of microorganisms, it would be advisable to add lime to the sludge in order to reach a $\mathrm{pH}>12$, maintaining this value during a certain period of time before adding other components according to the mixture desired. Since ash and sludge are very variable materials, results from other authors concerning microorganism survival differ and sometimes are not comparable, such those obtained by Papadimitriou et al. (2008) who reported 100\% removal of total coliforms (and similar results for E. coli) for different ratios of fly ash/ sewage sludge mixtures, at mixing times between 48 and $72 \mathrm{~h}$, and even with $\mathrm{pH}$ as low as 10 .

\section{Conclusion}

The first mixture studied (wood ash and sewage sludge) was in a stabilized state so that, independently of the amount of mixture used and the volume of water percolated, the $\mathrm{pH}$ value of the lixiviates remained close to neutral. Calcium, magnesium and potassium were released slowly in lixiviates, 
and, in addition, considerable amounts of organic carbon were leached, but this did not have a significant impact on solubilisation of heavy metals. Admixture of the ash and sludge achieved a stabilization of elements such as $\mathrm{Al}, \mathrm{Fe}$, $\mathrm{Mn}, \mathrm{Ni}, \mathrm{Co}, \mathrm{Cd}, \mathrm{Cr}$ and $\mathrm{Mo}$, that reduced their solubility if compared with that in the ash or sludge alone, also constraining the release of potentially harmful ions in lixiviates. Of the constraining factors, the most important appeared to be those related to the evolution of organic matter, and to the dissolution of oxides and carbonates present in the mixture. From the chemical point of view, there was not high risk of water pollution due to water flowing and leaching throw the ash-sludge mixtures assayed.

Even though quicklime was included in the second mixture, E. coli was able to proliferate, in certain grade, in it and its lixiviate, the highest count of E. coli being detected in the first sample, decreasing with oscillating values in the following lixiviates instead of showing a lineal decline. In fact, the medium, once the mixture placed in the column with improved conditions of high humidity, nutrients, and a more moderate $\mathrm{pH}$, enables a certain microbial proliferation, specially if compared with a more alkaline and less humid condition of the dried-solid mixture. In view of that, it would be advisable to add lime to the sludge in order to reach a $\mathrm{pH}>12$, maintaining this value during a certain period of time before adding other components, such as wood ash, giving place to a mixture with reduced counts of microorganisms.

Acknowledgments The authors thank the Xunta de Galicia (Government of Galicia, Spain) for support received under the Plan de $I+D$ (Grant Code PGIDIT2TAM02E), and the private company CEDIE, S.A. (Spain).

\section{References}

Abbott DE, Essington ME, Mullen MD, Ammons JT (2001) Fly ash and lime-stabilized biosolid mixtures in mine spoil reclamation: simulated weathering. J Environ Qual 30:608-616

Al-Wabel MA, Heil DM, Westfall DG, Barbarick KA (2002) Solution chemistry influence on metal mobility in biosolids-amended soils. J Environ Qual 31:1157-1165

APHA (1998) Standard methods for the examination of water and wastewater. American Public Health Associationm, Washington, $\mathrm{DC}$

Canet R, Pomares F, Tarazona F, Estela M (1998) Sequential fractionation and plant availability of heavy metals as affected by sewage sludge application to soil. Commun Soil Sci Plant Anal 29:697-716

Chirenje T, Rivero C, Ma LQ (2002) Leachability of $\mathrm{Cu}$ and $\mathrm{Ni}$ in wood ash-amended soil as impacted by humic and fulvic acid. Geoderma 108:31-34

Cravotta CA III (1998) Effect of sewage sludge on formation of acidic ground water at a reclaimed coal mine. Ground Water 36:9-19

Dalgren KE, Düker A, Arwidsson Z, Kronhelm T, van Hees PAW (2011) Re-cycling of remediated soil-evaluation of leaching tests as tools for characterization. Waste Manag 31:215-224
Demeyer A, Voundi Nkana JC, Verloo MG (2001) Characteristics of wood ash and influence on soil properties and nutrient uptake: an overview. Bioresour Technol 77:287-295

Gitari WM, Petrik LF, Key DL, Okujeni C (2010) Partitioning of major and trace inorganic contaminants in fly ash acid mine drainage derived solid residues. Int J Environ Sci Tech 7(3):519-534

Holmström SJM, Riise G, Strand LT, Geibe C, van Hees PAW, Wu Q, Lundström US (2003) Effects of lime and ash treatments on DOC fractions and low molecular weight organic acids in soil solutions of acidified podzolic soils. Water Air Soil Poll Focus 3:97-120

Jackson BP, Miller WP, Schumann AW, Sumner ME (1999) Trace element solubility from land application of fly ash/organic waste mixtures. J Environ Qual 28:639-647

Kahl J, Fernández I, Rustad L, Peckenham J (1996) Threshold application rates of wood ash to an acidic forest soil. J Environ Qual 25:220-227

Kuba T, Tschöll A, Partl C, Meyer K, Insam H (2008) Wood ash admixture to organic wastes improves compost and its performance. Agric Ecosyst Environ 127:43-49

Lundström US, Bain DC, Taylor AFS, van Hees PAW (2003a) Effects of acidification and its mitigation with lime and wood ash on forest soil processes: a review. Water Air Soil Poll Focus 3:5-28

Lundström US, Bain DC, Taylor AFS, van Hees PAW, Geibe CE, Holmström SJM, Melkerud P, Finlay R, Jones DL, Nyberg L, Gustafsson JP, Riise G, Strand L (2003b) Effects of acidification and its mitigation with lime and wood ash on forest soil processes in Southern Sweden, A joint multidisciplinary study. Water Air Soil Poll Focus 2:167-188

Mclaren RG, Clucas LM, Taylor MD, Hendry T (2003) Leaching or macronutrients and metals from undisturbed soils treated with metal-spiked sewage sludge. 1. Leaching of macronutrients. Aust J Soil Res 41:571-588

Núñez A, López E, Díaz-Fierros F (1997) Breakthrough of inorganic ions present in cattle slurry: soil column trials. Water Res 31:2892-2898

Papadimitriou CA, Haritou I, Samaras P, Zouboulis AI (2008) Evaluation of leaching and ecotoxicological properties of sewage sludge-fly ash mixtures. Environ Res 106:340-348

Pettersson A, Amand L-E, Steenari B-M (2008a) Leaching of ashes from co-combustion of sewage sludge and wood-part I: recovery of phosphorus. Biomass Bioenerg 32:224-235

Pettersson A, Amand L-E, Steenari B-M (2008b) Leaching of ashes from co-combustion of sewage sludge and wood-part II: the mobility of metals during phosphorus extraction. Biomass Bioenerg 32:236-244

Pitman RM (2006) Wood ash use in forestry-a review of the environmental impacts. Forestry 79(5):563-588

Pousada MY, Núñez A, Seoane S (2003) Evaluación de la mezcla de lodos residuales con cenizas de combustión de madereras como enmienda de suelos ácidos. In: Bienes R, Marqués MJ (eds) I Simposio Nacional sobre control de la erosión y degradación del suelo. CSIC, Madrid

Quiroga F, Pousada Y, Núñez A (2005) The pH and nutrient content of sewage sludge treated with limestone by-products and destined for agricultural use. In: Bernal P, Moral R, Clemente $\mathrm{R}$, Paredes C (eds) Sustainable organic waste management for environmental protection and food safety, vol I. FAO-CSIC, Murcia

Samaras P, Papadimitriou CA, Haritou I, Zouboulis AI (2008) Investigation of sewage sludge stabilization potential by the addition of fly ash and lime. J Hazard Mater 154:1052-1059

Schumann AW, Sumner ME (2000) Chemical evaluation of nutrient supply from fly ash-biosolids mixtures. Soil Sci Am J 64:419-426 
Shepherd MA, Withers PJ (2001) Phosphorus leaching from liquid digested sewage sludge applied to sandy soils. J Agric Sci Cambrige 136:433-441

Stiernström S, Hemström K, Wik O, Carlsson G, Bengtsson B-E, Breiholtz M (2011) An ecotoxicological approach for hazard identification of energy ash. Waste Manag 31:342-352

Sumner ME (2000) Beneficial use of effluents, wastes, and biosolids. Commun Soil Sci Plant Anal 31:1701-1715

Tulonen T, Arvola L, Ollila S (2002) Limnological effects of wood ash application to the subcatchments of Boreal, Humic Lakes. J Environ Qual 31:946-953
Wéry N, Lhoutellier C, Ducray F, Delgenès J-P, Jean-Jacques Godon J-J (2008) Behaviour of pathogenic and indicator bacteria during urban wastewater treatment and sludge composting, as revealed by quantitative PCR. Water Res 42:53-62

Yeheyis MB, Shang JQ, Yanful EK (2009) Long-term evaluation of coal fly ash and mine tailings co-placement: a site-specific study. J Environ Manag 91:237-244 